\title{
RESEARCH OF ORGANOLEPTIC PARAMETERS OF DUTCH CHEESE, PRODUCED FROM MILK OF COWS OF DIFFERENT BREEDS
}

\author{
Yuliya Nazarenko \\ Department of milk and meat technology \\ Sumy National Agrarian University \\ 160 Herasyma Kondrateva str., Sumy, Ukraine, 40021 \\ nazarenko.sumy@gmail.com \\ Volodymyr Ladyka \\ Department of Special Zootechnics \\ Sumy National Agrarian University \\ 160 Herasyma Kondrateva str., Sumy, Ukraine, 40021 \\ v.i.ladyka@ukr.net \\ Victor Opara \\ Department of feed technologies and animal feeding \\ Sumy National Agrarian University \\ 160 Herasyma Kondrateva str., Sumy, Ukraine, 40021 \\ vopara@ukr.net \\ Yuliia Pavlenko \\ Department of Special Zootechnology \\ Sumy National Agrarian University \\ 160 Herasyma Kondrateva str., Sumy, Ukraine, 40021 \\ jasjulia@ukr.net
}

\footnotetext{
Abstract

The aim of this research is to study an influence of types of different breeds of milk cows on organoleptic properties of Dutch cheese at different rations of their food. It allows to receive cheese with prognosticated quality characteristics and to manage marketing strategies at cheese realization.

The work presents the results of studying organoleptic properties of Dutch cheese, produced of milk of cows of different breeds, traditionally bred in the Northern-Eastern region of Ukraine.

For studying an influence of cows feeding on exclusive properties of hard cheese, traditional food rations of cows were added with forages of a silage-hay type with Lucerne as a main source of proteins ( $44 \%$ of the daily norm). Rations were practically identical with traditional ones by the content of energy and main food value factors and in general corresponded to norms of cows feeding. It has been demonstrated, that the high mark of cheese, up to 45 points for the taste and smell and total point mark 99 of 100 possible was obtained as a result of changing food rations at the expanse of introducing Lucerne silage in them. The data on optimization of food rations of certain cow breeds allow managing quality characteristics of milk and products of and are expedient for making cheese with unique regional characteristics.

At conducting the comparative organoleptic assessment, there has been revealed a distinct dependence between a point mark of quality parameters of cheese on a breed of milk cows, and also on food rations of them. At the silage-hay food ration of animals, the received Dutch cheese had higher quality characteristics after 60 days of storage than cheese samples, obtained of cow milk at the traditional food ration.
}

Keywords: unique organoleptic properties, Dutch cheese, breed of cows, food ration, point mark.

DOI: $10.21303 / 2504-5695.2019 .00843$

(C) Yuliya Nazarenko, Volodymyr Ladyka, Victor Opara, Yuliia Pavlenko

\section{Introduction}

A necessity of conducting scientific-research works at creating modern high-quality milk products is a requirement of the present day. The role of each step in forming taste peculiarities 
of cheeses still not completely studied [1, 2]. Different countries - Italy, France, Spain - accumulated the great experience of cheese-making traditions, each region has its unique types of cheese, known throughout the world $[3,4]$. At developing technologies of keeping and feeding animals, the quality of milk changes, in which result products of it also have other properties. That is why continuous studies of technological properties, physical-chemical parameters and organoleptic characteristics are needed for regulating production processes and managing the products' quality [5-7].

Important parameters, influencing the purchasing attractiveness of cheeses are organoleptic characteristics that create individual characteristics of a product and its distinctive features, typical for a concrete region $[8,9]$. It is necessary to establish a connection between certain keeping conditions, genetic factors and organoleptic parameters [10] for managing the technological process and obtaining Dutch cheese of the stable quality for managing marketing strategies.

The aim of this research is to study an influence of types of different breeds of milk cows on organoleptic properties of Dutch cheese at different rations of their food. It allows to produce a product with prognosticated taste characteristics by the genetic factor and changes in animals' food rations.

\section{Materials and methods of studying organoleptic parameters of Dutch cheese, obtained of cow milk at different food rations}

The studies were conducted on the base of the learning-research farm "Vivarium" of the Sumy national agrarian university (NAU), according to the program of scientific work on preserving the population of the brown breed under conditions of the Northern-Eastern region of Ukraine.

Milk for cheese production was received of three types of milk cows, of 5 heads in each group. Animal were kept in equal conditions. The first group is the Ukrainian brown milk breed, the second one - Lebedin breed, the third one - Simmental breed. In the research process three sessions of cheese production of milk of each cow group took place, separately, by each food ration. There were totally produced 9 parties of cheese of Dutch type, according to the traditional technological scheme of production of this type of cheeses [11].

The scheme of feeding cows was the following: 1 - the preliminary period - silage-hay ration; 2 - the first research period (25 days) - silage-hay ration; 3 - transition period (15 days); 4 - second research period ( 25 days) - ration of silage-hay type using Lucerne silage.

It must be noted, that for getting more reliable results, milk for Dutch cheese production was used only after the transition period that took place during no less 15 days for forming the stable influence of feeding on parameters of the product.

Dutch cheese for the study was produced in two stages. At the first stage there was used milk, received at the traditional silage-hay food type. After changing the food ration for the silage-hay with using Lucerne silage, the second stage of the cheese production process was realized. Dutch cheese was produced by the traditional classic scheme for this products type [11], taking into account requirements to the quality of this cheese type [12]. After finishing the technological production process, considered as cheese ripening in cheese production, all its parameters were studied for the correspondence to normative documents [12]. The analysis of products was conducted after finishing the ripening technological process that had taken place during 60 days at temperature $12-14{ }^{\circ} \mathrm{C}$ and relative humidity $85 \%$.

One of main criteria in assessing the quality of cheeses is their organoleptic assessment, and in this case it was a determining factor in revealing properties of cheese, unique for this region.

For studying organoleptic parameters of Dutch cheese, there were collected samples of Dutch cheese of three groups of milk cows, produced in different research periods.

Fig. 1 presents a sample of Dutch cheese, produced of milk of cows of the Ukrainian brown breed (UBB) at the silage-hay food ration with using Lucerne silage.

Fig. 2 presents a sample of Dutch cheese, produced of milk of cows of the Lebedin breed (LB) at the silage-hay food ration with using Lucerne silage. 


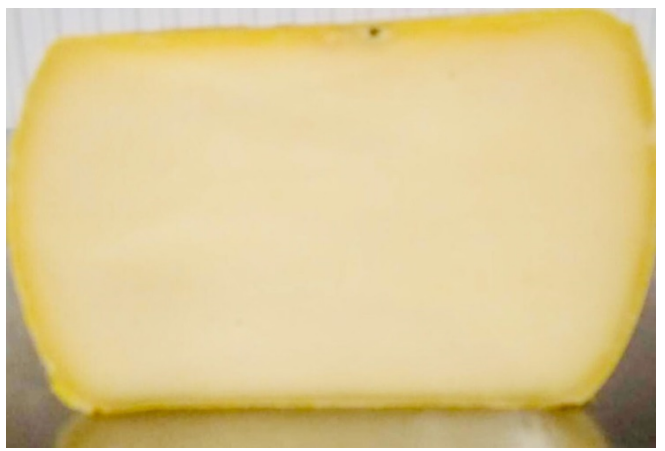

Fig. 1. Sample of Dutch cheese, produced of milk of cows of the Ukrainian brown breed (UBB)

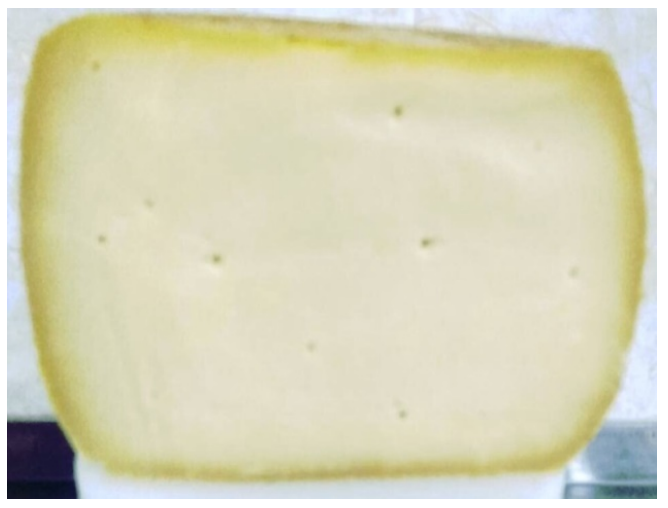

Fig. 2. Presents a sample of Dutch cheese, produced of milk of cows of the Lebedin breed (LB)

Fig. 3 presents a sample of Dutch cheese, produced of milk of cows of the Simmental breed (SB) at the silage-hay food ration with using Lucerne silage.

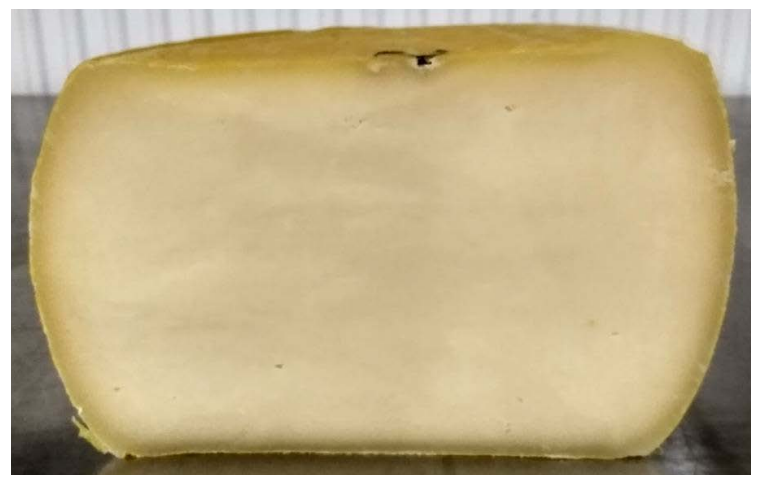

Fig. 3. Sample of Dutch cheese, produced of milk of cows of the Simmental breed (SB)

Three samples were selected for tasting of each group of cows depending on food rations of animals. There were totally selected six samples. The ones at the first research period (25 days) silage-hay ration:

1 sample - (UBB) sil.;

2 sample - (LB) sil.;

3 sample - (SB) sil.

The following three samples were presented for studying at the second research period (25 days). The ration of silage-hay type with using Lucerne silage:

1 sample - (UBB) luc.;

2 sample - (LB) luc.;

3 sample - (SB) luc. 
According to the rules of assessing organoleptic parameters, a sample was taken from each package unit by a cheese probe, presented on Fig. 4, inserting it in $3 / 4$ of the head depth.

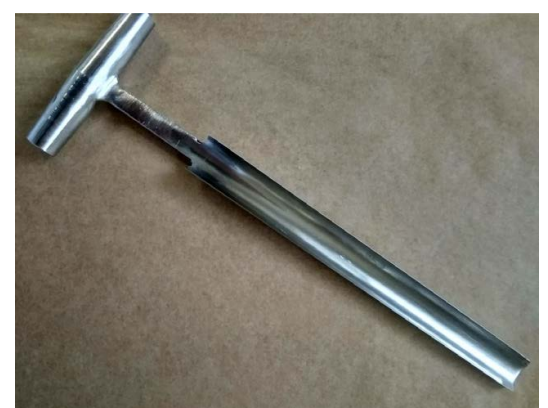

Fig. 4. Probe for taking cheese samples

The quality of organoleptic parameters was assessed at temperature $18-20^{\circ} \mathrm{C}$, for the correspondence to normative documents for this product type [12].

Dutch cheese was assessed by 100 point system, according to the traditional organoleptic quality assessment $[13,14,15]$.

100 -point assessment included the following parameters:

- taste and smell - 45 points;

- consistence -25 points;

- dough color -5 points;

- outlook - 10 points;

- package and marking -5 points (at absence of a package this index is added to the total point mark).

Points for each parameter had been summed up and a conclusion about the cheese quality was made $[12,13]$.

The upper bast layer (near $1 \mathrm{~cm}$ ) had been taken from the pulled column, as it is presented on Fig. 5, and all further studies of organoleptic parameters were realized by the sample of 4,0-4,5 cm, mass 35-45 grams [12, 13].

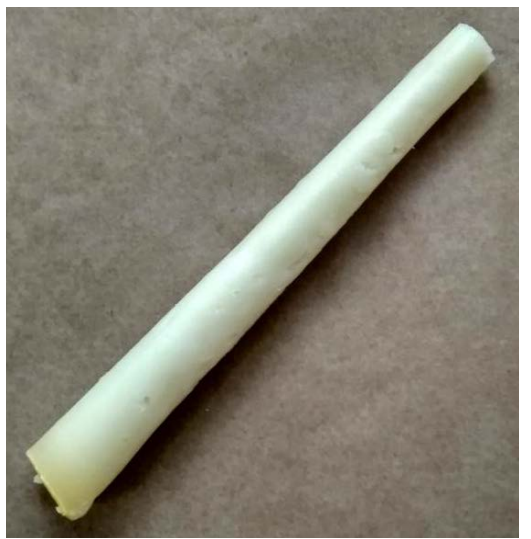

Fig. 5. Outlook of a sample of Dutch cheese, taken for tasting

\section{The results of tasting Dutch cheese of cow milk of different breeds}

The first assessed parameter was the outlook. As far as all samples of cheese were produced under laboratory conditions, their form resulted in decreasing a point mark. But other parameters, such as thin even crust, tightly adjoining the cheese surface, without defects were assessed rather highly.

The second and most important parameter was the taste and smell. The most expressed cheese smell [14] was observed in cheeses of milk of cows of the Ukrainian brown breed (UBB) and Lebedin (LB) at feeding by Lucerne silage. 
According to normative documents, the consistence of Dutch cheese must be delicate, plastic, homogenous along the whole mass. At assessing the presented samples, a preference was also given to: 1 sample - (UBB) luc.; and 2 sample - (LB) luc.

The figure with small eyespots of even form, placed along the whole cheese head was most distinct in 1 sample - (UBB) luc.; and 2 sample - (LB) luc.

The most typical color of cheese dough - from the light yellow to the more expressed was observed also in 1 sample - (UBB) luc.; and 2 sample - (LB) luc.

As a result of tasting, there was conducted the comparative characteristic of organoleptic parameters of Dutch cheese of the three groups of cows, depending on their breed, before and after improving food rations.

The tasting commission of three persons conducted the comparative assessment of the produced experimental cheeses [15]. (A control was not used at tasting, only the experimental samples were compared).

The dependence on the improved ration was obvious for the group of the Ukrainian brown breed, was especially expressed relative to the aroma-smell parameters (Fig. 6).

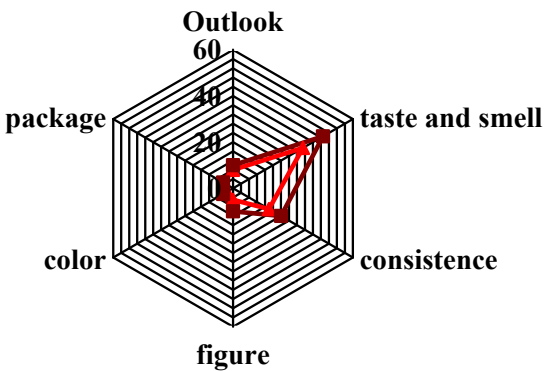

$\multimap 1$ sample (UBB) sil.

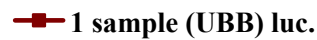

Fig. 6. Comparative characteristic of the point quality assessment of Dutch cheese, produced of milk of the Ukrainian brown breed of cows (UBB) at the different food rations

The other bright representative was a sample of Dutch cheese, produced of milk of cows of the Lebedin breed. The taste, smell and consistence of the product were most brightly expressed at the food ration with using Lucerne silage. Cheese was remarkable for its pleasant taste. The results of comparative analysis for this group are presented on Fig. 7.

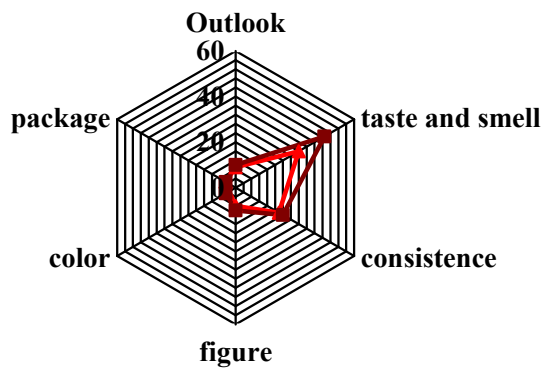

$\rightarrow 2$ sample (LB) sil. $\quad \rightarrow-2$ sample (LB) luc.

Fig. 7. Comparative characteristic of the point quality assessment of Dutch cheese, produced of milk of the Lebedin breed of cows (LB) at the different food rations

The distinctive features of Dutch cheese, produced of milk of Simmental breed are presented on Fig. 8. As a result of improving the food ration, the organoleptic parameters essentially improved, but less brightly expressed changes of the taste and smell took place. 


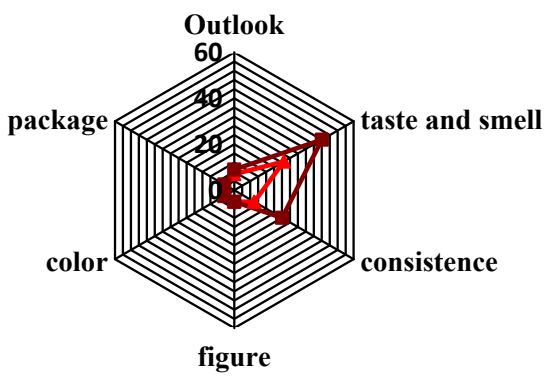

$\rightarrow 3$ sample (LB) sil.

$\rightarrow-3$ sample (LB) luc.

Fig. 8. Comparative characteristic of the point quality assessment of Dutch cheese, produced of milk of the Simmental breed of cows (SB) at the different food rations

The conducted tasting has proved that cheeses of the Dutch type, produced of milk of the different cow groups with using Lucerne silage, had the higher point mark. They had the more correct form, plastic consistence, even light-yellow color. Eyespots, obtained as a result of using special cultures of sour-milk microorganisms were evenly distributed along the whole surface and had the correct round form.

\section{Conclusions}

The parameters of cheese suitability of milk of cows of the Ukrainian brown and Lebedin breeds are rather high, but not always taken into account at cheese production. The studies of the organoleptic parameters of Dutch cheese, produced of these two cow breeds at the traditional and improved food rations, demonstrate that new improved hard cheeses with high taste characteristics may be obtained by genetic factors and change of the forage content. The obtained data may be extrapolated on different regions for getting cheeses with given characteristics.

Based on the conducted organoleptic assessment, it has been established, that the breed of cows and their food ration essentially influence the cheese quality.

Further studies, directed on investigating the dependence between quality parameters and regional peculiarities of cow breeding are expedient.

The obtained results allow to create a technology of producing unique, authentic craft cheeses of milk of cows of the Ukrainian brown and Lebedin breeds in the Northern-Eastern part of Ukraine.

It has been established, that the use of Lucerne silage positively influences the organoleptic parameters of Dutch cheese. The taste, smell and consistence of the product are most brightly expressed.

\section{References}

[1] Bergamaschi, M., Bittante, G. (2018). From milk to cheese: Evolution of flavor fingerprint of milk, cream, curd, whey, ricotta, scotta, and ripened cheese obtained during summer Alpine pasture. Journal of Dairy Science, 101 (5), 3918-3934. doi: https://doi.org/10.3168/jds.2017-13573

[2] Bergamaschi, M., Cipolat-Gotet, C., Stocco, G., Valorz, C., Bazzoli, I., Sturaro, E. et. al. (2016). Cheesemaking in highland pastures: Milk technological properties, cream, cheese and ricotta yields, milk nutrients recovery, and products composition. Journal of Dairy Science, 99 (12), 9631-9646. doi: https:// doi.org/10.3168/jds.2016-11199

[3] Zendri, F., Ramanzin, M., Cipolat-Gotet, C., Sturaro, E. (2016). Variation of milk coagulation properties, cheese yield, and nutrients recovery in curd of cows of different breeds before, during and after transhumance to highland summer pastures. Journal of Dairy Research, 84 (01), 39-48. doi: https:// doi.org/10.1017/s0022029916000583

[4] Benedet, A., Manuelian, C. L., Penasa, M., Cassandro, M., Righi, F., Sternieri, M. et. al. (2018). Factors associated with herd bulk milk composition and technological traits in the Italian dairy industry. Journal of Dairy Science, 101 (2), 934-943. doi: https://doi.org/10.3168/jds.2017-12717 
[5] Tkachenko, N. A., Nekrasov, P. O., Vikul, S. I. (2016). Optimization of formulation composition of health whey-based beverage. Eastern-European Journal of Enterprise Technologies, 1 (10 (79)), 49. doi: https://doi.org/10.15587/1729-4061.2016.59695

[6] Bittante, G., Cecchinato, A. (2013). Genetic analysis of the Fourier-transform infrared spectra of bovine milk with emphasis on individual wavelengths related to specific chemical bonds. Journal of Dairy Science, 96 (9), 5991-6006. doi: https://doi.org/10.3168/jds.2013-6583

[7] Cipolat-Gotet, C., Cecchinato, A., De Marchi, M., Bittante, G. (2013). Factors affecting variation of different measures of cheese yield and milk nutrient recovery from an individual model cheese-manufacturing process. Journal of Dairy Science, 96 (12), 7952-7965. doi: https://doi.org/10.3168/jds.2012-6516

[8] Cipolat-Gotet, C., Cecchinato, A., Drake, M. A., Marangon, A., Martin, B., Bittante, G. (2018). From cow to cheese: Novel phenotypes related to the sensory profile of model cheeses from individual cows. Journal of Dairy Science, 101 (7), 5865-5877. doi: https://doi.org/10.3168/jds.2017-14342

[9] Sturaro, E., Thiene, M., Cocca, G., Mrad, M., Tempesta, T., Ramanzin, M. (2013). Factors influencing summer farms management in the Alps. Italian Journal of Animal Science, 12, 153-161.

[10] Salum, P., Govce, G., Kendirci, P., Bas, D., Erbay, Z. (2018). Composition, proteolysis, lipolysis, volatile compound profile and sensory characteristics of ripened white cheeses manufactured in different geographical regions of Turkey. International Dairy Journal, 87, 26-36. doi: https://doi.org/10.1016/j. idairyj.2018.07.011

[11] Skott, R., Robinson, R., Uilbi, R. (2005) Proizvodstvo syra. Syre, tekhnologii, retsepturi: nauchnye osnovy i tekhnologii. Sankt-Peterburg: Professiya, 460.

[12] DSTU 6003:2008. Syry tverdi (2009). Kyiv, 22.

[13] Rodrigues, L., Machado, M., Pinheiro, C. (2018). Cheese: Food Perception and Food Choice. Recent Patents on Food, Nutrition \& Agriculture, 9 (2), 104-110. doi: https://oi.org/10.2174/2212798410666 180705092257

[14] Gorbatova, K. K. (2010). Biokhimiya moloka i molochnykh produktov. Sankt-Peterburg: GIORD, 314.

[15] Sukhenko, Yu. H., Polishchuk, H. Ye., Ramanauskas, R. Y., Shynhareva, T. I. (2015). Tekhnolohiya syru. Kyiv: TsP «Komprynt», 412. 